\title{
THE POTENTIAL USE OF ANTI-NUTRITIONAL COMPOUNDS OF GADUNG TUBERS AS BIOPESTICIDES
}

\author{
Riva Ismawati ${ }^{1}$, Feni Nurhidayanti ${ }^{2}$, Theresya Amelya Dhewi ${ }^{3}$, Cucun Yuningsih ${ }^{4}$ \\ 1,2,3 Natural Science Education Study Program, University of Tidar \\ Magelang, 56116, Indonesia \\ ${ }^{4}$ Agrotechnology Study Program, University of Tidar \\ Magelang, 56116, Indonesia \\ ${ }^{1}$ rivaismawati@untidar.ac.id
}

DOI: https://doi.org/10.21107/jps.v8i2.9518/

\begin{abstract}
The use of gadung (Discorea hispida dennst.) tubers as a food source is not seen as an attractive option due to dioscorine and cyanide anti-nutritional compounds contained therein. The presence of dioscorine and cyanide compounds makes gadung tubers known as poisonous food. Although the community has known its poisonous nature, the use of gadung tubers as natural pesticides (biopesticides) is not commonly known by the community. They were using gadung tubers as biopesticides to provide the solution to unanswered problems caused by chemical pesticides. This article seeks to describe the potential use of anti-nutritional compounds of gadung tubers as biopesticides based on literature reviews. Various literature related to anti-nutritional compounds in gadung tubers and their use as biopesticides has been analyzed in depth. The literature review results show that dioscorine and cyanide antinutritional compounds are toxic and can be used as biopesticides. The effectiveness of gadung tubers on various agricultural pests depends entirely on the concentration of gadung tubers used. The use of gadung tubers as biopesticides is needed to increase and maintain agricultural land productivity and preserve natural resources.
\end{abstract}

Keywords: anti-nutritional compounds, dioscorine, cyanide, biopesticides .

\footnotetext{
${ }^{1}$ Corresponding Author
} 


\section{Ismawati}

\section{Introduction}

Gadung (Discorea hispida dennst.) tubers are carbohydrate-rich food sources commonly found in Indonesia. In addition, gadung tubers contain anti-nutritional compounds (dioscorine, histamine, saponins, and cyanogenic glycosides). These compounds make gadung tubers a less attractive food source to the community (Widiyanti \& Kumoro, 2017). Anti-nutritional compounds are defined as secondary metabolites produced by plants through secondary metabolic reaction pathways.

Gadung tubers are known to the community as poisonous. The toxicity of gadung tubers comes from the content of dioscorine and cyanide compounds. Dioscorine has a biting taste due to its tannin content. As secondary metabolite compounds produced in certain parts of plants, dioscorine and cyanide will be distributed to all plants. As a result, gadung tubers contain toxic compounds (Santi, 2010).

The presence of dioscorine and cyanide compounds poisonous in gadung tubers allows them to be used as natural pesticides (biopesticides) to replace chemical pesticides, which have various negative impacts if used continuously. The use of chemical pesticides can lead to pest and disease retention, new pest or disease emergence, and environmental pollution. Biopesticides made from natural and environmentally friendly materials are considered the right solution in replacing chemical pesticides.

Biopesticides offer several advantages compared to their chemical counterparts. First, biopesticides are more environmentally friendly. It is because biopesticides are quickly broken down into other forms. Thus, the toxic effects do not remain in the environment for a long time. Second, their residues on plants do not last long, so plants sprayed with biopesticides are safer for consumption. Third, biopesticides provide more value to the products because they can be selfmade by farmers to save costs. Fourth, biopesticides in integrated pest control do not cause pest retention (Astuti \& Widyastuti, 2017).

Sumartini (2016) stated that pests or pathogens that cause various diseases in plants vary greatly. Among them are planted hoppers and ladybugs on rice plants, borer in corn plants, lice, and armyworms on soybean plants. If agricultural pests are not handled properly, they will be detrimental to farmers because they can reduce productivity and quality of crop yields.
The Indonesians already know gadung tubers as poisonous, but they do not know the potential use of these tubers in handling pests. Therefore, biopesticides are becoming important due to the abundance of gadung tubers and a large number of agricultural businesses in Indonesia. Therefore, an in-depth review of active compounds in gadung tubers and their use as biopesticides based on previous research is needed. This article seeks to examine the potential use of antinutritional compounds in gadung tubers as biopesticides based on literature reviews.

\section{Research Methods}

This article writing implemented the literature review method. Various literature related to anti-nutritional compounds of gadung tubers and their potential use as biopesticides were analyzed. The information obtained was then compiled to be discussed further. The purpose of this research is to provide information related to bio pesticides from native plants of Indonesia. Therefore, it is expected to be a new reference for future research. The selection of the review topic was based on the use of gadung tubers as a bio pesticide. Antinutritional components are important to review because the chemical compounds in gadung tubers are the basic ingredients for making bio pesticides. In addition, it is necessary to study related to bio pesticides from gadung tubers. It aims to provide information on the effectiveness of bio pesticides from gadung tubers.

\section{Result and Discussion}

\section{Anti-nutritional Compounds of Gadung Tubers}

Anti-nutritional compounds are those that, when they managed to get into the body of living things, either directly or indirectly, in specific amounts, can cause metabolic disorders (Alsuhendra \& Ridawati, 2013). Anti-nutritional compounds in gadung tubers that can be used as biopesticides are described as follows.

\section{Dioscorine}

Dioscorine $\left(\mathrm{C}_{13} \mathrm{H}_{19} \mathrm{O}_{2} \mathrm{~N}\right)$ belongs to the pyran group, which contains six members of heterocyclic pyran rings. Dioscorine is a nonaromatic ring with five carbon atoms, one oxygen atom, and two double bonds (Kumoro, \& Hartati, 2015). The chemical structure of dioscorine is shown in Figure 1. 


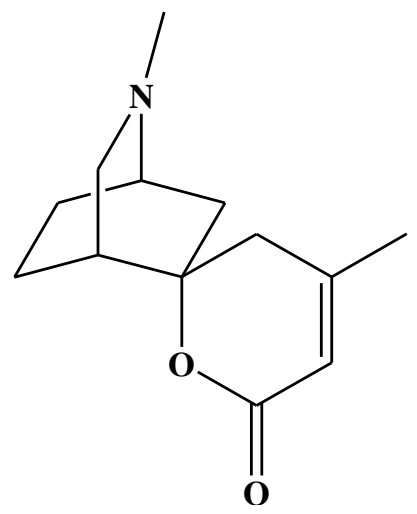

Figure 1. The chemical structure of dioscorine

Dioscorine can be found in gadung tubers and other tropical plant tubers. Dioscorine acts as a reserve protein and contributes up to $80 \%$ watersoluble protein from the total protein extracted from gadung (D. hispida) tubers (Lu et al., 2012). Dioscorine has a melting point of $54-55^{\circ} \mathrm{C}$. Moreover, dioscorine is entirely soluble in hydrophilic solvents such as water, ethanol, and acetone. It is slightly soluble in ether, benzene, and petroleum ether. The active side of dioscorine derives from its tertiary amine and carbonyl groups present in its molecular structure.

Dioscorine can be synthesized from trigonelline which is nicotinic acid methylated in its $\mathrm{N}$ atom. The biosynthetic mechanism of dioscorine is presented in Figure 2. This mechanism produces dumetorine as a by-product. Dumetorine is an alkaloid that can be found in Dioscorea dumetorum (Leete \& Michelson, 1988).<smiles>CC(C)(C#N)OC1OC(CO)C2OC1C(O)C2(O)O</smiles><smiles>[14CH3]</smiles><smiles>OCC1OC(O)C(O)C(O)C1O</smiles><smiles>CC(C)(O)C#N</smiles><smiles></smiles>

Figure 2. The biosynthetic mechanism of dioscorine (Leete \& Michelson, 1988)

Dioscorine is neurotoxic (toxic to nerves) and is a convulsant that causes paralysis to the central nervous system in animals (BPPOM, 2015). Treatments of gadung tubers juice at $20 \%, 40 \%$, and $80 \%$ in male mice showed muscle nerve poisoning, diarrhea, behavior, breathing, and death of the test animals. The LD50 calculation based on Indonesian pharmacopeia is $0.09 \mathrm{~g} / \mathrm{kgBB}$ and is included in the toxic category (Posangi, 2014). This poisonous nature of dioscorine allows it to be used as biopesticides to replace chemical pesticides.

\section{Cyanide Acid}

Cyanide is a chemical compound that contains $\mathrm{C} \equiv \mathrm{Na}$ group. Gadung tubers contain cyanide acid (HCN) in their free form and bound form of cyanogenic glycosides. High concentrations of cyanide, especially in its free form of $\mathrm{HCN}$, are lethal. Fresh gadung tubers can contain $469.5 \mathrm{mg} / \mathrm{kg}$ of free-form cyanide (BPPOM, 2015).

Cyanide acid ( $\mathrm{HCN})$ is a colorless gas and has a characteristic of almond-like odor. $\mathrm{HCN}$ is a weak acid with a vapor pressure of $630 \mathrm{mmHg}$ at $20^{\circ} \mathrm{C}$, a boiling point of $25.7^{\circ} \mathrm{C}$, and is highly volatile in water with a $\mathrm{pH}$ below 9 (Dzombak, Ghosh, \& Wong-Chong, 2005).

Cyanogenic glycosides are precursors of free-form cyanide in gadung tubers. The cyanogenic glycosides found in gadung tubers are in linamarin, as shown in Figure 3. Linamarin is also known as phaseolunatin, one of the various cyanogenic glycosides in higher plants (Alsuhendra \& Ridawati, 2013). Plants that contain linamarin usually also contain lotaustralin or methyl linamarin.

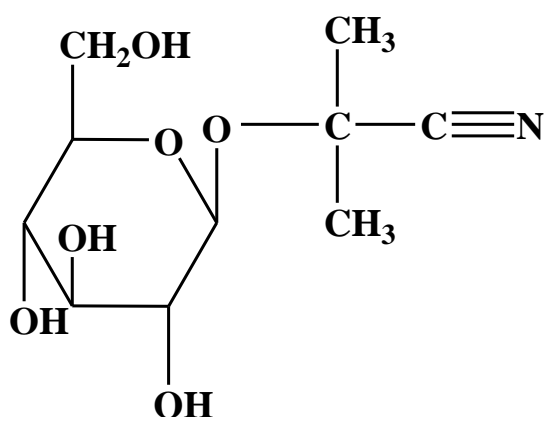

Figure 3. Linamarin 


\section{Ismawati}

The cyanogenic glycosides are release toxic (cyanide acid) by enzymatic reactions, as shown in Figure 4 . The enzymes involved in this reaction are linamarase or $\beta$-glucosidase and hydroxyethyl lyase enzymes. Linamarase enzyme hydrolyzes cyanogenic glucose to glucose and cyanohydrin compounds. Meanwhile, the hydroxyethyl lyase enzyme breaks cyanohydrin to produce acetone and cyanide acid compounds. Linamarase and hydroxyethyl lyase enzymes can be found in plants containing cyanogenic glycosides (Alsuhendra \& Ridawati, 2013).

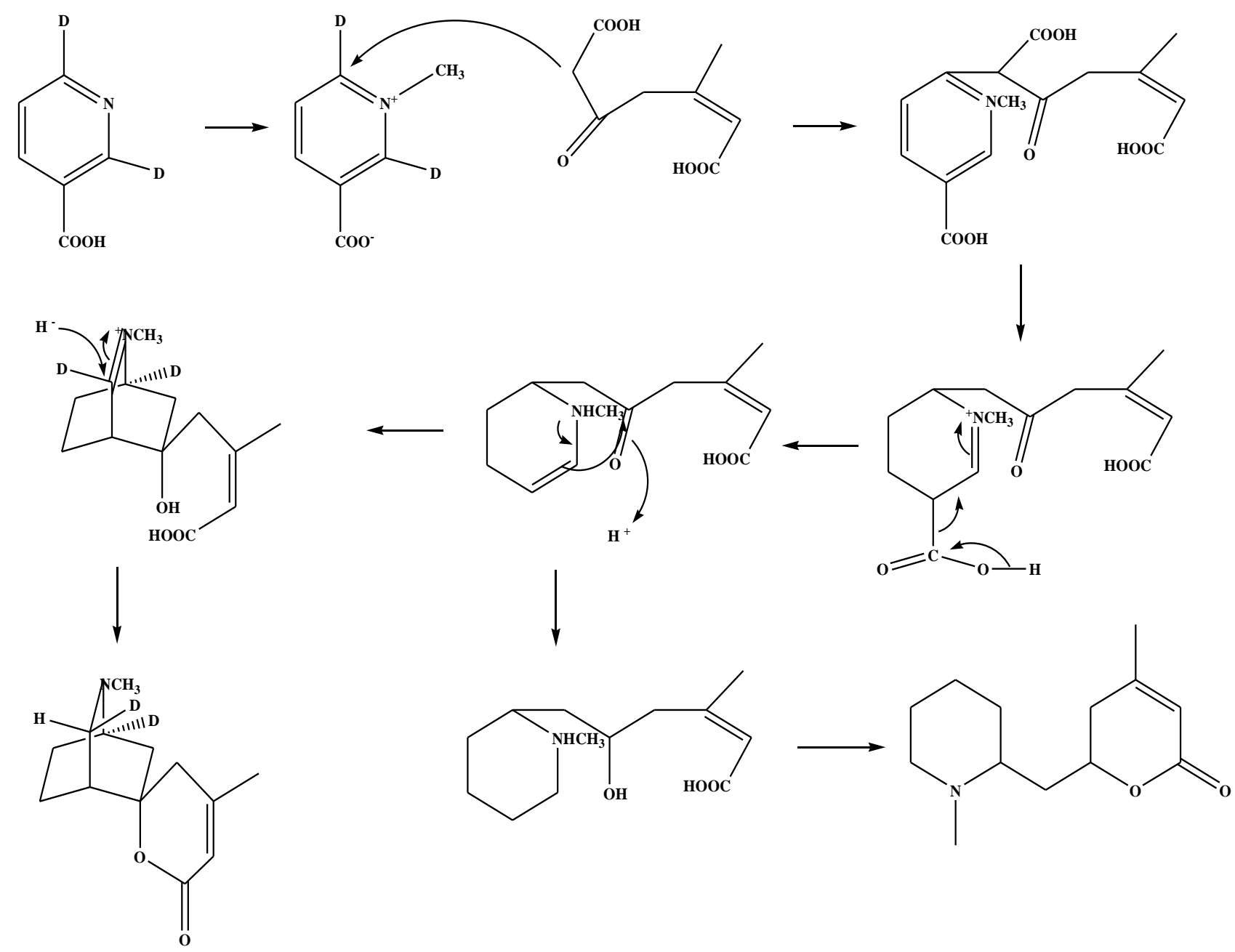

Figure 4. Breakdown of linamarin to cyanide acid

The breakdown of cyanogenic glycosides into $\mathrm{HCN}$ with the help of enzymes occurs when plant tissues are damaged. In gadung tubers, cyanogenic glycosides are located in the vacuole. At the same time, linamarase and hydroxyethyl lyase enzymes are found in the cytoplasm. If plant tissues are damaged, the two components will interact to produce HCN (Alsuhendra \& Ridawati, 2013).

Cyanide's lethal property comes from its ability to diffuse rapidly into tissues and bind to target organs in a short time. Cyanide can bind and de-activate several enzymes, especially those containing iron and cobalt. As a result, structural integrity and enzyme effectiveness are lost (Cahyawati, 2017).
Cyanide can form irreversible bonds with cytochrome oxidase a3 in mitochondria. The formation of these bonds causes intracellular hypoxia. Cytochrome oxidase a3 plays an essential role in reducing oxygen to water through the phosphorylation oxidation process. The bond between cyanide and ferric $\left(\mathrm{Fe}^{3+}\right)$ in cytochrome oxidase a3 results can inhibit terminal enzymes in the respiratory chain, electron transport chain, and phosphorylation oxidation process (Cahyawati, 2017).

The mechanism playing a role in cyanide poisoning and the inhibition mechanism of cytochrome a3 oxidation includes inhibition of carbonic anhydrase enzyme. Cyanide bonding with 


\section{The Potential Use of Anti-nutritional Compounds of Gadung Tubers As Biopesticides}

carbonic anhydrase causes hemoglobin rendered unable to transport oxygen (Cahyawati, 2017).

\section{Reviewing the Use of Gadung Tubers as Biopesticides}

Utami and Haneda (2012) have studied the bioactivity of gadung tubers extract in controlling bagworm pests (P. plagiophleps) on a laboratory scale. Their research results showed that gadung tubers extract was effective against larval mortality, inhibited insect pests' growth and development, and inhibited their feeding activity. Meanwhile, Rozi, Febrianti, \& Telaumbanua (2018) have examined the use of gadung tubers starch as bioinsecticides for stink bugs in rice plants. Their research was conducted using five treatment groups with five repetitions. Each treatment used ten stink bugs. The results showed a significant effect of using gadung tubers starch on handling stink bugs in rice plants. Muhidin, Muchtar, \& Hasnelly (2020) Muhidin have tested gadung tuber extract to control brown planthopper pests in rice plants. The test results showed that the dose of gadung tubers of 100 grams/liter for 65 hours gave maximum pest mortality of $87 \%$, while the application for 69 hours gave a mortality of $89.40 \%$

Posmaningsih, Purna, \& Sali (2014) have shown the effectiveness of using gadung tubers in controlling rat pests. Their research results showed several differences in the number of dead rats in the control group and the treatment group. The most effective level of gadung tubers for killing rats was at $30 \%$. It was possible because it had met the LD 50 limit. Ningsih \& Utami (2013) have also researched the use of gadung tubers to filtrate against pests. The results showed that using a filtrate combination between gadung tubes, soursop leaves, and the Indian nettle plant was more effective against the mortality rate of S. litura larvae than a single biopesticide administration.

\section{Conclusion}

The anti-nutritional compounds of gadung tubers in the form of dioscorine and cyanide acid are toxic. They allow the use of gadung tubers as natural pesticides (biopesticides). The composition and concentration of gadung tubers must be adjusted to pest types as they have different resistance and immunity.

\section{References}

Alsuhendra, R., \& Ridawati. (2013). Bahan toksik dalam Makanan. Bandung: PT. Remaja Rosdakarya.

Astuti, W., \& Widyastuti, C. R. (2017). Pestisida organik ramah lingkungan pembasmi hama tanaman sayur. Rekayasa: Jurnal Penerapan Teknologi dan Pembelajaran, 14(2), 115120.

BPPOM, 2015. Mengenal Gadung dan Resiko Keracunannya, (January, $1^{\text {st }}, 2021$ ). Retrieved from http://ik.pom.go.id/v2015/artikel/Mengenal \%20Gadung\%20dan\%20Resiko\%20Keracu nannya.pdf

Cahyawati, P. N. (2017). Keracunan Akut Sianida. WICAKSANA: Jurnal Lingkungan dan Pembangunan, 1(1), 80-87.

Dzombak, D. A., Ghosh, R. S., \& Wong-Chong, G. M. (Eds.). (2005). Cyanide in water and soil: chemistry, risk, and management. CRC press.

Kumoro, A. C., \& Hartati, I. (2015). Microwaveassisted extraction of dioscorin from Gadung (Dioscorea hispida Dennst) tuber flour. Procedia Chemistry, 14, 47-55.

Leete, E., \& Michelson, R. H. (1988). Biosynthesis of dioscorine from trigonelline in Dioscorea hispida. Phytochemistry, 27(12), 3793-3798.

Lu, Y. L., Chia, C. Y., Liu, Y. W., \& Hou, W. C. (2012). Biological activities and applications of dioscorins, the major tuber storage proteins of yam. Journal of traditional and complementary medicine, 2(1), 41-46.

Muhidin, M., Muchtar, R., \& Hasnelly, H. (2020). Pengaruh Insektisida Nabati Umbi Gadung terhadap Wereng Batang Cokelat (Nillavarpata lugens Stall) Pada Tanaman Padi. Jurnal Ilmiah Respati, 11(1), 62-68.

Ningsih, U., \& Utami, T. R. I. (2013). Pengaruh filtrat umbi gadung, daun sirsak dan herba anting-anting terhadap mortalitas larva Spodoptera litura. LenteraBio: Berkala Ilmiah Biologi, 2(1), 33-36.

Posangi, T. H. (2014). Uji toksisitas akut LD50 sari umbi gadung (Dioscorea hispida 


\section{Ismawati}

Dennst) pada mencit jantan (Mus musculus). Skripsi, 1(821410001).

Posmaningsih, D. A. A., Purna, I. N., \& Sali, I. W. (2014). Efektivitas Pemanfaatan Umbi Gadung Dioscorea Hispida Dennust) Pada Umpan Sebagai Rodentisida Nabati Dalam Pengendalian Tikus. Jurnal Skala Husada, 11(1), 79-85.

Rozi, Z. F., Febrianti, Y., \& Telaumbanua, Y. (2018). Potensi sari pati Gadung (Dioscorea hispida L.) sebagai bioinsektisida hama Walang Sangit pada tanaman Padi (Oryza sativa L.). Biogenesis: Jurnal Ilmiah Biologi, 6(1), 18-22.

Santi, S. R. (2010). Senyawa Aktif antimakan dari Umbi Gadung (Dioscorea hispida Dennst). Jurnal Kimia, 4(1), 71-78.

Sumartini, S. (2017). Biopestisida untuk Pengendalian Hama dan Penyakit Tanaman Aneka Kacang dan Umbi. Iptek Tanaman Pangan, 11(2).

Utami, S., \& Haneda, N. F. (2012). Bioaktivitas ekstrak umbi gadung dan minyak nyamplung sebagai pengendali hama ulat kantong (Pteroma plagiophleps Hampson). Jurnal Penelitian Hutan Tanaman, 9(4), 209-218.

Widiyanti, M., \& Kumoro, A. C. (2017). Kinetika detoksifikasi umbi gadung (Dioscorea hispida Dennst.) secara fermentasi dengan kapang Mucor racemosus. Reaktor, 17(2), $81-88$ 